ОБҐРУНТУВАННЯ ТА ПРАКТИЧНІ МЕХАНІЗМИ ВПРОВАДЖЕННЯ ПЕДАГОГІЧНИХ УМОВ ФОРМУВАННЯ МІЖЕТНІЧНОЇ ТОЛЕРАНТНОСТІ МАЙБУТНІХ УЧИТЕЛІВ ПОЧАТКОВОЇ ШКОЛИ У ПРОЦЕСІ ПРОФЕСІЙНОЇ ПІДГОТОВКИ

\title{
SUBSTANTIATION AND PRACTICAL MECHANISMS FOR INTRODUCING THE PEDAGOGICAL CONDITIONS FOR THE FORMATION OF INTERETHNIC TOLERANCE OF FUTURE PRIMARY SCHOOL TEACHERS IN THE PROCESS OF PROFESSIONAL TRAINING
}

\begin{abstract}
Стаття присвячена обгрунтуванню доцільності впровадження педагогічних умов у систему професійної підготовки майбутніх учителів початкової школи. Педагогічні умови розуміємо як сукупність конкретних практико-орієнтованих заходів, що сприяють досягненню майбутніми вчителями початкових класів належного рівня міжетнічної толерантності, забезпечують удосконалення профресійної підготовки та позитивно впливають на всі структурні компоненти міжетнічної толерантності. Виокремлено такий спектр педагогічних умов: створення розвивального полікультурного освітнього середовища у ЗВО, забезпечення системного методичного супроводу пізнавальної діяльності на основі запровадження освітніх інновачій; організація проєктно-дослідницької діяльності майбутніх учителів у галузі вивчення традицій, етнокультури; удосконалення особистісних якостей і збагачення практичного досвіду в контексті міжетнічної толерантності засобами тренінгу. Для їхнього практичного впровадження запропоновано конкретні практичні дії. Так, ми пропонуємо: 1) насичення освітнього середовища закладу вищоі освіти спеціальними етнокультурними впливами; 2) активне використання для розвитку пізнавальної діяльності інтерактивних рольових ігор, дебатів для фрормування профресійного досвіду конструктивного міжкультурного діалогу; 3) стимулювання студентів до проєктно-дослідницької діяльності, яка базується на розробленні проєктів та використанні методу аналізу конкретної ситуації міжкультурного змісту; 4) використання тренінгової технології, що передбачає залучення студентів до міні-лекчій, вправ, ігор, рольових ситуацій, дискусій, мозкових итурмів. Педагогічні умови, які ми підібрали, позитивно впливають на мотиваційно-ціннісну, когнітивно-пізнавальну, діяльнісно-поведінкову та рефлексивнотворчу ссрери майбутніх учителів, які працюватимуть у полікультурному середовищі початкової школи.
\end{abstract}

Ключові слова: педагогічні умови, міжетнічна толерантність, майбутні вчителі початкової школи, фахова підготовка.

The article is devoted to substantiation of expediency of introduction of pedagogical conditions in the system of professional training of future teachers of elementary school. The pedagogical conditions are understood as a set of concrete practical-oriented measures that promote the achievement of the proper level of interethnic tolerance of future primary school teachers and provide improved training and positively affect all structural components of interethnic tolerance. Such a range of pedagogical conditions is singled out: creation of a developing multicultural educational environment in the HEl; provision of systemic methodical support of cognitive activity on the basis of introduction of educational innovations; organization of design and research activity of future teachers in the field of studying traditions and ethnoculture; improvement of personal qualities and enrichment of practical experience in the context of interethnic tolerance by means of training. Specific practical actions are proposed for their practical implementation. Thus, we propose: 1) the saturation of the educational environment of a higher education institution with special ethnocultural influences; 2) actively used for the development of cognitive activity interactive roleplays, debates for the formation of professional experience in constructive intercultural dialogue; 3) stimulated students to design and research activity, which is based on the development of projects and the use of the method of analysis of a specific situation of intercultural content; 4) the use of training technology, which involves students in mini-lectures, exercises, games, role-playing situations, discussions, brainstorming. The pedagogical conditions that we have chosen have a positive influence on the motivational-value, cognitive, activity-behavioral and reflexive-creative areas of future teachers who will work on the multicultural environment of the elementary school.

Key words: pedagogical conditions, interethnic tolerance, future teachers of elementary school, professional training.
Постановка проблеми в загальному вигляді. У час інноваційних змін в освітній галузі українське суспільство має фрундаментальну потребу у кваліфрікованих майбутніх педагогах, які працюватимуть у початковій школі. Поділяємо думку А. Фурмана й О. Шаюк про те, що нині «однією з найбільш значущих у фрорматі міжнародного, міжконфесійного та окультуреного спілкування є проблема толерантності» [16, с. 31]. Для педагога початкової школи, що досить часто працює в полікультурному середовищі, на перший план виходить міжетнічна толерантність, яку розглядаємо як інтегративну особистісно-професійну якість, що заснована на позитивній етнічній ідентичності, виявляється в шанобливому ставленні до представників іншого етносу та передбачає активну неконфліктну взаємодію на основі врахування всіх аспектів міжнаціонального спілкування.

Щоби знання відповідали новим вимогам, необхідно запровадити низку змін в організації 
навчально-пізнавальної діяльності, що передбачають оновлення освітнього процесу, шляхом розроблення цілісної системи фрормування в майбутніх педагогів початкової школи міжетнічної толерантності, яка передбачає впровадження обґрунтованих педагогічних умов, що позитивно вплинуть на весь освітній процес та підсилять рівень міжетнічної толерантності. Такі дії приведуть до підготовки висококваліфікованого фрахівця, який вільно володіє набутими знаннями з основ міжетнічної толерантної поведінки, має сорормовані практичні вміння і навички професійної роботи зі своїми учнями, їхніми батьками та колегами в полікультурному освітньому середовищі початкової школи.

Аналіз останніх досліджень і публікацій. Толерантність як наукова дефрініція була в центрі уваги українських науковців О. Брюховецької, М. Вихристюк, Л. Гончаренко, Л. Гончарук, Л. Жгун, О. Зарівни, В. Логвіненко, Н. Ружицької, М. Телічко, А. Фурмана, О. Шаюк та ін. З'ясовано, що практичні шляхи формування толерантності вивчали І. Войтенко, О. Волошина, Н. Голова, О. Демиденко, І. Кривошапка, Ж. Конотоп, Н. Стасюк, Т. Фокіна й ін. Загальні теоретичні та методологічні аспекти міжетнічної толерантності досліджували Б. Андрієвський [1], С. Капідінова [9], А. Павлик [15]. У працях О. Демиденко, В. Зими, Н. Кусяк, О. Матієнко, Л. Смеречинської доведено, що толерантність має посісти належне місце в образі сучасного вчителя.

Виділення не вирішених раніше частин загальної проблеми. На основі аналізу окреслених публікацій установлено, що у професійній діяльності вчителя початкової школи толерантність як вияв поваги до представників різних етносів, релігій і культур має стати умовою високого рівня його профресіоналізму та посісти вагоме місце. Як засвідчують результати констатувального етапу експериментального дослідження, лише традиційними засобами сорормувати міжетнічну толерантність студентів фракультетів початкової освіти досить складно. Саме тому викладачам ЗВО доцільно проводити системну та послідовну роботу в зазначеному контексті та цілеспрямовано працювати над запровадженням додаткових чинників - педагогічних умов.

3 метою дотримання об'єктивності зазначимо, що педагогічні умови формування толерантності були в центрі уваги Р. Кострубаня [10], Н. Орловської [14]. Зокрема, ми поідтримуємо позицію Р. Кострубаня в тому, що для вчителя початкових класів толерантність - «багатокомпонентна особистісна та професійна якість, яка дозволяє адаптуватися до складних умов сучасного професійного соціуму, органічно сприймати його мінливість, уміти бачити багатогранність навколишнього світу, поєднуючи власне бачення з оцінками інших учасників освітнього процесу» [10, с. 7]. Однак ми не можемо цілком використати ці напрацювання, адже вони лише опосередковано стосуються фрормування міжетнічної толерантності майбутніх учителів початкової школи та не охоплюють усього спектра діяльності в полікультурному середовищі початкової школи. Тому розпочато власні дослідження означених питань.

Мета статті - обґрунтувати сукупність педагогічних умов, які впливають на фрормування міжетнічної толерантності майбутніх учителів початкової школи, та висвітлити практичні механізми їх упровадження.

Виклад основного матеріалу. У контексті реалізації Державного стандарту загальної початкової освіти [6] особливої актуальності набувають проблеми нового змісту профресійної підготовки вчителів початкових класів із високим рівнем міжетнічної толерантності, які можуть ефрективно працювати в полікультурному освітньому середовищі. Методологічною основою у вивченні питання обрання спектра педагогічних умов, що покладені в основу системи фрормування міжетнічної толерантності майбутніх учителів початкової школи у процесі фрахової підготовки, стали фрілософські роботи Дж. Локка, Т. Гоббса, І. Канта, які представляють толерантність як суспільну норму життя людини і держави, здатну примирити людей різних націй і віри. У психологопедагогічній площині в основу нашої діяльності покладено фрундаментальну тезу етнопсихології й етносоціології про взаємозв'язок етнічної ідентичності та міжетнічної толерантності (Дж. Беррі).

Вивчення напрацювань Н. Бирко, О. Волошиної, Р. Кострубаня, Н. Орловської, П. Степанова, Г. Шеламової й ін., використання методу експертних оцінок, а також власний досвід викладацької діяльності дозволили нам дійти висновку про доцільність упровадження в освітній процес профресійної підготовки майбутніх учителів початкової школи цілісного спектра взаємопов'язаних педагогічних умов. Педагогічні умови розуміємо як сукупність конкретних практико-орієнтованих заходів, що сприяють досягненню майбутніми вчителями початкових класів належного рівня міжетнічної толерантності та забезпечують удосконалення їхньої професійної підготовки, позитивно впливаючи на всі структурні компоненти міжетнічної толерантності. Ми прагнули таким чином підібрати умови, щоб вони здійснювали цілісний психологопедагогічний вплив на мотиваційно-ціннісну, когнітивно-пізнавальну, діяльнісно-поведінкову та реорлексивно-творчу сорери майбутніх учителів, які працюватимуть у полікультурному середовищі початкової школи. Отже, виокремлено чотири педагогічні умови:

1) створення розвивального полікультурного освітнього середовища у 3ВО;

2) забезпечення системного методичного супроводу пізнавальної діяльності на основі запровадження освітніх інновацій; 
3) організація проєктно-дослідницької діяльності майбутніх учителів у галузі вивчення традицій, етнокультури;

4) удосконалення особистісних якостей і збагачення практичного досвіду в контексті міжетнічної толерантності засобами тренінгу.

Обґрунтуємо вибір саме такого спектра педагогічних умов та зупинимося на аналізі практичних механізмів їхнього впровадження у професійну підготовку майбутніх учителів початкової школи.

Так, перша педагогічна умова націлена на створення розвивального полікультурного середовища в навчальному закладі, де студенти здобувають освіту. В основі вибору цієї умови покладено міркування Б. Буяка про те, що освітнє середовище навчального закладу має бути «носієм духовно-інтелектуального потенціалу» [2, с. 5]. Ми використали також пораду М. Мінакова про те, що освітній заклад «має бути тим середовищем, що не тільки об'єднує в собі знання і засоби їх передавання та отримання, а й яке максимально сприяє самопродукуванню та розширенню духовно-інтелектуальних можливостей суспільства» [12, с. 15]. Тобто ЗВО - це середовище, де студенти соціалізуються та готуються до просресійної діяльності, тому його освітнє середовище має бути наповнене реальним змістом у контексті фрормування міжетнічної толерантності.

У нашому розумінні, розвивальне полікультурне освітнє середовище ЗВО - це таке освітнє середовище, яке насамперед має вагомий позитивний вплив на розвиток чуттєвої сорери як основоположної якості особистості майбутніх учителів початкової школи, що включає здатність відчувати, сприймати, уявляти, співпереживати, співчувати представникам інших етносів. Таке розвивальне середовище спрямовано на врахування вікових особливостей студентів під час відбору творів етнічної культури народів регіону, врахування специфіки етнопсихологічних особливостей елементів культури рідного краю; виховних можливостей суб'єктно-суб'єктних відносин у діалозі культур; комплексного впливу культури на етнотолерантності ставлення до осіб, які належать до різних етносів.

У практичному контексті для впровадження першої умови ми пропонуємо використовувати під час вивчення навчальної дисципліни «Початкова школа Закарпаття» (магістри, 1-й курс, 2-й семестр / 3 кредити) такі стимули впливу:

1) організація виставок малюнків, які належать до різних етнічних груп, використання фротографрій, на яких зображені елементи національних костюмів, відновлення національних орнаментів;

2) використання різних елементів культури, що належать певному регіону для тематичного оформлення інтер'єру навчальних аудиторій;

3) цитування літературних джерел різних етносів, використання речей домашнього вжитку, інтер'єру житлових приміщень під час проведення виховної роботи зі студентами.

Запропоновані впливи розширюють емоційнообразну сореру студентів, дозволяють їм зрозуміти розмаїття полікультурних явищ регіону, тому позитивно впливають на фрормування міжетнічної толерантності. Уважаємо, що позитивно спрямоване полікультурне освітнє середовище, яке активно фрункціонує у ЗВО, дозволяє розглядати мотиваційно-ціннісну сореру студентів як цілісну систему, здатну абстрагуватися, і на основі цього виявити основні тенденції фрормування міжетнічної толерантності через позитивне ставлення до культури різних народів і етносів. Очікуємо від запровадження цієї умови позитивних змін в емоційному сприйнятті «чужих» національних традицій, розширення спектра світоглядних та ціннісних орієнтирів щодо налагодження ефективного спілкування та, за потреби, ведення переговорного процесу між представниками різних культур.

Обираючи другу умову - забезпечення системного методичного супроводу пізнавальної діяльності на основі запровадження освітніх інновацій, - ми дослухалися до поради А. Зимульдінової стосовно того, що «одним із провідних напрямів реформування освіти вищої школи $€$ впровадження педагогічних технологій, спрямованих на підвищення в майбутніх учителів інтересу до навчальної діяльності, активного самопізнання, розвитку творчих здібностей» [8, с. 10]. Зокрема під час вивчення навчальної дисципліни «Університетська освіта в Україні та країнах Східної Європи: історія і сучасність» (магістри, 1-й курс, 2-й семестр / 3 кредити) ми активно використовували інтерактивні рольові ігри для формування профресійного досвіду конструктивного міжкультурного діалогу («Польща і Україна: діалог культур», «Україна і Румунія: національні моделі поведінки», «Україна та Угорщина: особливості національного характеру»). Такі рольові ігри надавали можливість студентам познайомитися 3 національнокультурними цінностями різних народів, водночас акцентувалася увага на загальнолюдських цінностях, властивих цим культурам. Рольова діяльність сприяла становленню позитивної етнічної ідентичності студентів, яка виступала основою для фрормування міжетнічної толерантності майбутніх учителів початкової школи.

Під час семінарських занять ми практикували проведення дебатів із метою розвитку логічного і критичного мислення студентів і срормування самоконтролю. Дебати фрокусували увагу студентів на проблемі таких загальнолюдських цінностей, як право, мораль, моральність, що сприяло визнанню їхньої істотної ролі в побудові рівноправного діалогу і співпраці між народами в полікультурному середовищі початкової школи. Водночас розвивалися такі значущі якості майбутніх 
фрахівців, як партнерська взаємодія, уміння вести цивілізовану дискусію.

У практичному контексті очікуємо від запровадження цієї педагогічної умови розширення теоретичних знань у контексті толерантності, її видів та орорм. У нашому розумінні активне впровадження освітніх інноваційних технологій спричинить позитивні зміни щодо розуміння студентами цінностей, норм і правил іншої культури на когнітивному рівні.

Третя умова спрямована на організацію проєктно-дослідницької діяльності майбутніх учителів у галузі вивчення традицій, етнокультури. До уваги взято думку $€$. Полат про те, що проєктно-дослідницька діяльність «передбачає сукупність творчих, дослідницьких, пошукових і проблемних методів» [13, с. 57]. Обираючи третю педагогічну умову, ми також враховували пораду О. Жерновникової [7] стосовно того, що майбутні вчителі у процесі фрахової підготовки мають опановувати: основи педагогічного проєктування; способи розроблення проєктів як видів професійної діяльності вчителя; механізми рефлексії власної проєктувальної діяльності. Цінність проєктно-дослідницької діяльності полягає в активній самостійній роботі як основному засобі особистісно-професійного розвитку студентів. У педагогічному розумінні її есрективність зумовлена тим, що вона, по-перше, має розвиваючий характер; по-друге, має особистісно-орієнтоване спрямування; по-третє, стимулює пізнавальну діяльність. У нашому розумінні, проєктна діяльність володіє позитивом тому, що в її основі лежить ідея, спрямована на отримання результату, що орієнтований на самостійну діяльність студентів - індивідуальну, парну або групову.

Погоджуємося з Є. Лодатком і Л. Кондрашовою, що 3 учителем початкової школи «пов'язуються не тільки освітні досягнення молодших школярів, а й розвиток їхнього світовідчуття і світосприйняття, фрормування самосвідомості, з'ясування свого зв'язку із соціумом, його ціннісними орієнтирами, національною культурою, традиціями, ментальними феноменами» [11, с. 89]. У практичній площині під час вивчення студентами навчальної дисципліни «Сучасні педагогічні технології у початковій школі» (магістри, 1-й курс, 2-й семестр, 3 кредити) ми активно стимулювати студентів до проєктно-дослідницької діяльності, яка включала метод аналізу конкретної ситуації міжкультурного змісту. Студенти розробляли власні проєкти з конкретними прикладами роботи в полікультурному середовищі початкової школи.

Ми очікуємо, що під час розроблення творчих проєктів у студентів фоомуються професійні й особистісні компетенції (встановлюється контакт, налагоджується робота в команді, фрормується відповідальність, упевненість у собі, фрормуються аналітичні здібності та гнучкість мислення). Проєктна діяльність студентів не лише цілеспрямовано впливала на поглиблення теоретичних знань про національно-психологічні особливості конкретного етносу, а й дозволяла адекватно сприймати конкретні норми міжнаціонального спілкування та розширювала спектр практичних умінь й навичок. Тобто передусім ця умова націлена на оволодіння практичними вміннями міжкультурного діалогу із представниками інших народів, дозволяла усвідомлювати значущість загальнолюдських цінностей у контексті уявлень про культурні ціннісних свого й інших народів, які сприяють становленню міжетнічної толерантності у студентів.

Четверта педагогічна умова передбачала активне використання тренінгової технології. Ми опиралися на бачення науковців і практиків (Н. Голова [2], Л. Гончарук [4], О. Демиденко [5]) про те, що під час тренінгу відбувається розкриття особистісної сфери членів групи та її психокорекція на основі міжособистісної взаємодії. Саме тренінг активізує розвиток професійно важливих якостей, сприяє розкриттю внутрішнього потенціалу особистості, позитивно впливає на фрормування рис характеру, які сприяють досягненню високого рівня сорормованості міжетнічної толерантності. Тобто вважаємо, що найкращим методом, що підвищує ефективність фрормування міжетнічної толерантності та безпосередньо впливає на рефлексивно-творчу сореру, є тренінг.

Для впровадження цієї педагогічної умови нами під час викладання майбутнім учителям початкової школи такої навчальної дисципліни, як «Теорія і практика фрормування міжетнічної толерантності майбутніх учителів початкової школи» (магістри, 2-й курс, 3-й семестр, 3 кредити) упроваджено комплекс тренінгових занять (10 занять). Тренінг розглядався нами як істотний чинник для розвитку особистості майбутнього педагога і $€$ ключовим моментом фрормування його особистісно-профресійних рис, які впливають на стан міжетнічної толерантності. У процесі тренінгу зроблено акцент на фрормування теоретичних знань адекватної орієнтації в полікультурному середовищі, він розвивав практичні вміння та навички конструктивного діалогу із представниками іншого етносу, сприяв підвищенню здатності до емпатії та рефлексії, а також дозволяв відкоригувати інтолерантні та конфрліктогенні стереотипи, які були у студентів на початку експериментального дослідження. Розроблений тренінг як групова фрорма роботи охоплював міні-лекції, різноманітні проблемні завдання та вправи, ігри, рольові ситуації, дискусії, мозкові штурми, презентації.

Отже, можемо передбачити, що обґрунтовані педагогічні умови відображають компонентноструктурний склад міжетнічної толерантності, позитивно впливають на процес ії фрормування. Уважаємо, що системне впровадження в освітній процес ЗВО комплексу педагогічних умов сприя- 
тиме ефрективній організації процесу фрахової підготовки майбутніх учителів початкової школи.

Висновки. В умовах соціально-економічної нестабільності та зниження моральної культури спостерігається загострення етнонаціональної напруженості, а також зростає кількість міжнаціональних конорліктів, можливе поширення етнофобії в поліетнічному середовищі. 3 метою попередження та подолання цих негативних явищ майбутні вчителі початкової школи повинні мати високий рівень міжетнічної толерантності. Для її ефективного фрормування у ЗВО необхідно розробити цілісну систему, яка охоплює дієві та практико-спрямовані педагогічні умови (створення розвивального полікультурного освітнього середовища у ЗВО; забезпечення системного методичного супроводу пізнавальної діяльності на основі запровадження освітніх інновацій; організація проєктно-дослідницької діяльності майбутніх учителів у галузі вивчення традицій, етнокультури; удосконалення особистісних якостей і збагачення практичного досвіду в контексті міжетнічної толерантності засобами тренінгу).

У подальших дослідженнях ми зупинимося на аналізі практичних результатів фрормувального етапу експериментального дослідження щодо впровадження в освітній процес професійної підготовки майбутніх учителів початкової школи виокремлених педагогічних умов.

\section{БІБЛІОГРАФІЧНИЙ СПИСОК:}

1. Андрієвський Б. Толерантність як засіб міжнаціональної культури спілкування. Таврійський вісник освіти. 2005. № 1. С. 109-116.

2. Буяк Б. Глобалізаційні виклики сучасній університетській освіті. Наукові записки Тернопільського національного педагогічного університету імені Володимира Гнатюка. Серія «Педагогіка». 2014. № 2. C. 3-11.

3. Голова Н. Виховуємо толерантність: я - толерантна особистість : корекційно-виховний тренінг. Завуч. Шкільний світ. 2012. № 21. С. 29-30.
4. Гончарук Л. Толерантність у нашому житті : тренінгове заняття. Психолог. 2016. № № 11/12. C. 12-14.

5. Демиденко О. Жила-була толерантність... Тренінгове заняття з педагогами. Психолог дошкілля. 2018. № 12. С. 7-13.

6. Державний стандарт початкової загальної освіти. Початкова школа. 2011. № 7. С. 1-18.

7. Жерновникова О. Підготовка майбутнього вчителя до навчального проектування як психологопедагогічна проблема. Педагогіка та психологія : збірник наукових праць. Харків : Вид-во ТОВ «Щедра садиба плюс», 2015. Вип. 49. С. 193-202.

8. Зимульдінова А. Підготовка майбутніх учителів до впровадження педагогічних технологій у школі І ступеня. Початкова школа. 2009. № 10. С. 10-12.

9. Капідінова С. Толерантність як чинник розвитку культури міжетнічних відносин студентів : автореф. дис. ... канд. психол. наук: 19.00.05. Київ, 2015. $18 \mathrm{c}$.

10. Кострубань Р. Формування толерантності у майбутніх учителів у процесі гуманітарної підготовки у педагогічних коледжах : автореф. дис. ... канд. пед. наук: 13.00.04. Хмельницький, 2016. 20 с.

11. Лодатко Є., Кондрашова Л. Вчитель початкової школи у соціокультурному вимірі суспільства : навчальний посібник. Київ : Слово, 2015. 232 с.

12. Мінаков М. Університет: криза ідентичності. Критика. 2003. № 3 (65). С. 8-15.

13. Полат Е., Бухаркина М., Моисеева М. Новые педагогические и инорормационные технологи в системе образования : учебное пособие для студентов педагогических вузов и системы повышения квалификации педагогических кадров / под ред. Е. Полат. 4-е изд., стер. Москва : Академия, 2009. 272 с.

14. Орловська Н. Педагогічні умови впровадження ідей педагогіки толерантності. Завуч. Шкільний світ. 2012. № 21. С. 8-11.

15. Павлик А., Щербина Л. Толерантність і міжетнічні відносини: за і проти : година спілкування до Міжнародного дня толерантності : 7-9 кл. Шкільний cвim. 2016. № 19. С. 16-21.

16. Фурман А., Шаюк О. Толерантність як предмет онтофреноменологічного дискурсу. Психологія $і$ суспільство. 2015. № 3. С. 31-61. 